\title{
ARTICLE
}

\section{Three widespread founder mutations contribute to high incidence of $X$-linked juvenile retinoschisis in Finland}

\author{
L aura H uopaniemi ${ }^{1,2}$, A nne R antala ${ }^{1,2}$, Henrik Forsius ${ }^{2}$, M irja Somer ${ }^{3}$, \\ A lbert de la Chapelle ${ }^{2,4}$ and Tiina A litalo ${ }^{1,2,5}$ \\ ${ }^{1}$ D epartment of M edical G enetics, U niversity of $\mathrm{H}$ elsinki, $\mathrm{H}$ elsinki, Finland \\ ${ }^{2}$ The Folkhalsan Institute of G enetics, D epartments of M olecular G enetics and Population G enetics, Helsinki, \\ Finland \\ ${ }^{3}$ The Family Federation of Finland, $\mathrm{H}$ elsinki, Finland \\ ${ }^{4}$ Comprehensive $\mathrm{C}$ ancer Center, $\mathrm{O}$ hio State University, O hio, USA \\ ${ }^{5}$ D epartments of $\mathrm{O}$ bstetrics and Gynecology, H elsinki U niversity Central Hospital, Helsinki, Finland
}

\begin{abstract}
$\mathrm{X}$-linked juvenile retinoschisis (RS) is a recessively inherited disorder causing progressive vitreoretinal degeneration in males. The gene defective in retinoschisis, XLR S1, has recently been identified and characterised. This gene consists of six exons encoding a protein with a putative role in cell-cell adhesion and phospholipid binding. J uvenile retinoschisis has been actively studied in Finland over the past 30 years, with over 300 diagnosed R S patients. B ased on genealogical studies, approximately $70 \%$ of the Finnish R S patients originate from Western Finland and $20 \%$ from Northern Finland. In this study, one third of the known Finnish R S patients were screened for mutations of the XLRS1 gene. H aplotype analysis, using nine microsatellite markers spanning $1 \mathrm{cM}$ in $\mathrm{Xp22.2}$, suggested the segregation of eight different mutations in these families. To identify mutations, the six exons were amplified by PCR and analysed by single strand conformation analysis, followed by direct sequencing of the PCR products. We identified seven distinct missense mutations, all in exons 4 and 6 . The mutations in exon 4, 214G $>A$ and 221G $>T$, are accountable for R S in Western Finland. A third mutation in exon 4, 325G $>C$, gives rise to $R S$ in Northern Finland. These three founder mutations are the predominant cause of $\mathbf{R} \mathbf{S}$ in Finland and their existence explains the high incidence of the disease. The identification of mutations common in genetically isolated populations, such as Finland, allows the diagnosis of patients with an atypical R S phenotype and enables nationwide carrier testing and improved genetic counselling.
\end{abstract}

Keywords: X-chromosome; retinoschisis; mutation screening; haplotypes

\section{Introduction}

X-linked juvenile retinoschisis (RS; MIM 312700) belongs to the group of vitreoretinal dystrophies. The

Correspondence: Tiina A litalo PhD, U niversity of Helsinki, D epartment of $M$ edical $G$ enetics, The Folkhal san Institute of G enetics, M annerheimintie 97, $00280 \mathrm{H}$ elsinki, Finland. Tel: +35894713602; Fax: +358961585632 and +35894714906; E-mail: talitalo@cc.helsinki.fi and tiina.alitalo@huch.fi

R eceived 10 A ugust 1998; revised 140 ctober 1998; accepted 9 N ovember 1998 disease causes progressive impairment of vision with variable degrees of severity. The onset of the disease appears to be from the abnormal development of the cortical vitreous, probably already at the foetal stage. ${ }^{1}$ Patients are typically diagnosed at school age, although retinal changes may be present at birth. ${ }^{1,2}$ The visual acuity is commonly poor (0.1-0.6) in children, and deterioration of vision occurs in the fourth and fifth decades of life because of macular atrophy. The most serious sight-threatening complications are vitreous 
Table 1 STSs used in this study

\begin{tabular}{|c|c|c|c|}
\hline M arker & Primer sequences $\left(5^{\prime}->3^{\prime}\right)$ & A nnealing temperature & Product size (bp) \\
\hline CA 1 & $\begin{array}{l}\text { TCCTGATTTAAGGATCCCCC } \\
\text { TTATTGGGGGAAGAGTTCCA }\end{array}$ & $57^{\circ} \mathrm{C}$ & $163-153$ \\
\hline CA 3 & $\begin{array}{l}\text { TCA A A A ATCA GCACCA A A A GA A } \\
\text { TCCATG TGTTTTCATAG CTTGG }\end{array}$ & $57^{\circ} \mathrm{C}$ & $273-259$ \\
\hline TA A A & $\begin{array}{l}\text { CAGCTATTTGGGAGGCTGA G } \\
\text { TTGAGGTGCAAGTGTCA A G G }\end{array}$ & $58^{\circ} \mathrm{C}$ & $204-188$ \\
\hline CA 6 & $\begin{array}{l}\text { CTTAG CTGGCCATTTA GG GA } \\
\text { TCCССTTTCA A A A CA G GA A }\end{array}$ & $55^{\circ} \mathrm{C}$ & $187-179$ \\
\hline TA A A 2 & $\begin{array}{l}\text { A ATTGCTTGA ATCCA G GA G G } \\
\text { G GCTCTTTCCACTCCA GTCA }\end{array}$ & $58^{\circ} \mathrm{C}$ & $222-206$ \\
\hline
\end{tabular}

haemorrhage and retinal detachment., ${ }^{3,4}$ There is no known therapy to cure the degenerative process.

Females heterozygous for the RS gene are symptomless, and clinical detection of carriers is not definitive with present methods. A woman can get the disease only if she has an affected father and a heterozygous mother, usually as a result of a consanguineous marriage. A few affected females have been described in the literature, ${ }^{5-7}$ including one with Turner syndrome. ${ }^{8}$

Several linkage studies have localised the RS gene to a 1CM interval DXS418-DXS999/DXS7161 on $X$ p22. ${ }^{9-13}$ This region has further been covered with YAC clones ${ }^{12,14-16}$ and a PAC contig. ${ }^{16}$ The entire RS candidate region has now also been sequenced by the Sanger Centre ${ }^{17}$ in collaboration with the R etinoschisis Consortium.

The gene responsible for retinoschisis, XLRS1, was recently isolated by positional cloning strategies. ${ }^{18}$ In this original study, nine mutations of the XLRS1 gene were identified in nine individual RS families. In addition, the Retinoschisis Consortium has recently performed a collaborative study and identified 82 disease-causing mutations. ${ }^{19}$ The XLRS1 gene encodes a protein of 224 residues whose expression is limited to the retina. The XLR S1 protein contains a 23 amino acid residue leader sequence as well as a conserved discoidin motif at the $\mathrm{C}$-terminus. Since other peptide sequences with a discoidin motif in the carboxyterminal part of the protein are known to mediate cell-to-cell interactions, it is assumed that the XLRS1 protein is involved in cell-to-cell adhesion. ${ }^{18,20}$ The precise function of the XLRS1 protein, or the pathophysiology of the disease, is still largely unknown.

$X$-linked retinoschisis is very common in Finland with a prevalence of $>1: 17000 .^{21}$ Moreover, the majority of patients come from the Western province of Satakunta, while the province of Oulu in the Northern part of the country is another area of considerable density. ${ }^{22}$ This report describes the mutations found in the X L RS1 gene of Finnish R S patients. The aim of the study was to identify all Finnish founder haplotypes and mutations as well as to estimate the age of the founder mutations. These results will benefit all Finnish RS families. A Iso, the mutation findings in a thoroughly studied isolated population can be useful when estimating the world-wide frequency of RS.

\section{Materials and Methods}

Patients and Control DNAs

Members of 55Finnish retinoschisis families (117 affected males, one female) were included in the haplotype and mutation analyses. Thirty-nine of these families had already taken part in our previous linkage studies. ${ }^{13}$ Blood samples were obtained from 16 new families. $\mathrm{H}$ igh molecular weight genomic DNA was prepared from blood leukocytes of the R S patients by standard methods. O ne ophthalmologist (HF) saw all the patients and confirmed the diagnosis. The birthplaces of the ancestors were determined by genealogical studies. Clinical studies of the R S families, as well as the classification of the patients as severe, moderate and mild cases, have been published earlier. 22,23 DNA s from 75 healthy blood donors were used as normal controls. ${ }^{24}$

Genetic Analysis with New Microsatellite Markers The Sanger Centre had sequenced the PAC clones which cover the RS candidate region. We screened the entire sequence $^{17}$ and found 13 new polymorphic markers. Primer sequences and PCR conditions for the markers which had more than three alleles, ie CA 1, CA 3, TAAA, CA 6, and TA A A 2 are listed in Table 1. Primers were designed using the Primer 3 program. ${ }^{25}$ The data on allele sizes and frequencies were derived from 100 normal $X$ chromosomes (Table 2). The alleles were numbered consecutively according to decreasing size. Primer sequences and PCR amplification conditions for 
Table 2 A llele sizes and frequencies for the new microsatellite markers. A llele frequencies were obtained from 100 normal X chromosomes

\begin{tabular}{|c|c|c|c|c|c|c|c|c|c|}
\hline \multicolumn{10}{|c|}{ M arkers } \\
\hline \multicolumn{2}{|c|}{ CA 1} & \multicolumn{2}{|c|}{ CA 3} & \multicolumn{2}{|c|}{ TAAA } & \multicolumn{2}{|c|}{ CA 6} & \multicolumn{2}{|c|}{ TAAA 2} \\
\hline Size (bp) & Freq. & Size & Freq. & Size & Freq. & Size & Freq. & Size & Freq. \\
\hline 1. 163 & 0.04 & 1. 273 & 0.02 & 1. 204 & 0.01 & 1. 187 & 0.59 & 1. 222 & 0.01 \\
\hline 2. 161 & 0.04 & 2. 271 & 0.06 & 2. 200 & 0.28 & 2. 185 & 0.02 & 2. 218 & 0.04 \\
\hline 3. 159 & 0.72 & 3. 269 & 0.13 & 3. 196 & 0.62 & 3. 183 & 0.24 & 3. 214 & 0.30 \\
\hline 4. 157 & 0.01 & 4. 267 & 0.48 & 4. 192 & 0.08 & 4. 181 & 0.01 & 4. 210 & 0.63 \\
\hline 5. 155 & 0.02 & 5. 265 & 0.06 & 5. 188 & 0.01 & 5. 179 & 0.14 & 5. 206 & 0.02 \\
\hline 6. 153 & 0.17 & 6. 263 & 0.16 & & & & & & \\
\hline & & 7. 261 & 0.05 & & & & & & \\
\hline & & 8. 259 & 0.04 & & & & & & \\
\hline
\end{tabular}

Table 3 H aplotypes associated with Finnish R S patients at nine marker loci

\begin{tabular}{|c|c|c|c|c|c|c|c|c|c|}
\hline $\begin{array}{l}\mathrm{D} \text { istances } \\
\text { between } \\
\text { markers }\end{array}$ & M arker & $\begin{array}{l}\text { Western I } \\
214 G>A\end{array}$ & $\begin{array}{l}\text { Western II } \\
221 G>T\end{array}$ & $\begin{array}{l}\text { N orthern } \\
325 G>C\end{array}$ & $\begin{array}{l}\text { Fam } 41 \\
\text { no mut }\end{array}$ & $\begin{array}{l}\text { Fam } 36 \\
625 C>G\end{array}$ & $\begin{array}{l}\text { Fam } 39 \\
554 C>A\end{array}$ & $\begin{array}{l}\text { Fam } 5 \\
608 C>T\end{array}$ & $\begin{array}{c}\text { Fam } 2 \\
312 C>G\end{array}$ \\
\hline $30 \mathrm{kh}$ & DXS418 & 878 & 788 & 12 & 7 & 8 & 8 & 9 & 7 \\
\hline $270 \mathrm{~kb}$ & CA 1 & 333 & 333 & 3 & 3 & 3 & 3 & 3 & 5 \\
\hline $2 \mathrm{~kb}$ & DXS9911 & 666 & 777 & 5 & 5 & 5 & 5 & 6 & 5 \\
\hline 18 kb & CA 3 & 555 & 334 & 1 & 3 & 3 & 1 & 5 & 4 \\
\hline $180 \mathrm{~kb}$ & TAA A & 222 & 333 & 3 & 3 & 3 & 3 & 2 & 1 \\
\hline $\begin{array}{l}100 \mathrm{~kb} \\
\text { X L R S1 } \\
50 \mathrm{~kb}\end{array}$ & CA 6 & 333 & 111 & 1 & 1 & 1 & 5 & 3 & 3 \\
\hline $50 \mathrm{~kb}$ & TA A A 2 & 221 & 444 & 3 & 2 & 3 & 3 & 4 & 3 \\
\hline $100 \mathrm{~kb}$ & DXS999 & 333 & 111 & 1 & 3 & 5 & 7 & 9 & 7 \\
\hline & DXS7161 & 555 & 555 & 7 & 5 & 6 & 6 & 2 & 2 \\
\hline $\begin{array}{l}\text { No. of families with } \\
\text { this haplotype }\end{array}$ & & 2622 & 721 & 10 & 1 & 1 & 1 & 1 & 1 \\
\hline
\end{tabular}

the eight additional less informative markers are available on request.

For haplotype analysis, all the families were genotyped with the markers DX S418, CA 1, DX S9911, CA 3, TA A A , CA 6, TAAA 2, DXS999 and DXS7161 (Table 3). DNA samples were amplified by PCR using standard protocols and the above mentioned markers. A mplified products were separated on $6 \%$ polyacrylamide gels in $1 \times$ TBE as described earlier. ${ }^{13} \mathrm{~A}$ fter electrophoresis, the gels were visualised by silver staining. ${ }^{26}$

\section{Mutation Analysis}

For each patient, exons 1-6 and flanking sequences were amplified by PCR from genomic DNA. PCR primers and amplification conditions were those published earlier. ${ }^{18} \mathrm{M}$ utation search was performed by single strand conformation analysis (SSCA ). ${ }^{27} \mathrm{PCR}$ products were separated on $\mathrm{MDE}$ gels (Mutation Detection Enhancement, FMC (FMC BioProducts, R ockland, ME, USA ); $0.7 \times$ and $1 \times M D E)$ in $0.6 \times$ TBE buffer. Gels were run at room temperature with $10 \mathrm{~W}$ constant power for 14-20 hours and stained by silver staining. ${ }^{26}$ PCR products exhibiting aberrant SSCA patterns (Q iagen, Valencia, CA, USA) were purified by QIA quick purification columns ( $Q$ iagen) and sequenced directly in both directions by fluorescent automated sequencing (A BI373A). PCR products spanning the mutations found were also amplified from 100 control chromosomes, followed by SSCA.

Some of the mutations found could be detected by restriction enzyme analysis. These mutations had either created or caused a loss of a particular restriction site (Table 4). Genomic DNA was amplified as described earlier. 
In general, digestions of amplified exon products were performed in $1 \times$ reaction buffer using $10-20 \mathrm{U}$ of the restriction enzyme. The resulting fragments were electrophoresed through 2.5\% agarose gels (Sea Kem, FMC) and DNA visualised with ethidium bromide (Figure la).

\section{Results}

\section{Haplotype Analysis and Genealogical Investigations}

Based on the present and previous genealogical studies $^{22}$ and the new haplotype data, the 55 kindreds studied could be divided into four groups: A ) Western I families $(n=30)$ form a group of families whose ancestors were born in the Western part of Finland, near Pori. A Imost all ancestors of these families can be traced to one large pedigree, ${ }^{22}$ (H Forsius, personal communication, 1998). B) M ost ancestors of the Western II families $(n=10)$ originate in the neighbouring parishes near the town of Pori. Some families are at present living in Southern Finland. C) The Northern families $(n=10)$ are all related to each other, although the families are scattered over a large area. ${ }^{28} \mathrm{D}$ ) Individual families ( $n=5$ ) from the Southern, E astern and Northern parts of Finland are not related to any known RS family.

Table 3 summarises the genotypes of the R S patients in this study. If the most distal, highly mutable marker locus D X S418 is left out of the analysis, ${ }^{13}$ and mutations are allowed at the loci TAAA 2 and CA 3, a total of eight different haplotypes can be observed. We were not able to estimate the degree of linkage disequilibrium by allelic association due to the lack of recombinations in the ancestral haplotypes in each group.

\section{Identification of Mutations}

Since the haplotype data suggested that there might be eight different mutations, we searched for mutations in the representatives of these eight groups by SSCA. $D$ irect sequencing of PCR fragments showing mobility shifts revealed seven missense mutations (Table 4), all in exons 4 and 6.

Western I mutation was found in all the patients with a Western I haplotype. This mutation is caused by a $G$ to $A$ transition at position 214 of the CDNA. This change eliminates a Taql restriction site and alters the amino acid at position 72 from G lu to Lys (Table 4). The loss of a Taql site in exon 4 PCR products was used to identify the 214G > A alleles in all the R S patients with the same haplotype (Table 3; Figure 1a). O ur female R S patient had the Western I mutation in both of her $X$ chromosomes.

Western II mutation in exon 4 is caused by a $\mathrm{G}$ to $T$ transversion at position 221 of the CD NA, resulting in a Gly to Val change at amino acid position 74 . The mutation in all the patients with the Western II haplotype could be identified by restriction enzyme assay. The mutation creates a TspRI recognition site that can be detected by TspRI digestion since the normal sequence lacks the recognition site for this enzyme. B ecause the restriction enzyme based method is not yet reliable enough to be used routinely in mutation detection we use the SSCA method (Figure 1b). A ll the N orthern patients carried the $325 \mathrm{G}>\mathrm{C}$ mutation which alters the amino acid at position 109 from G ly to A rg, and can only be detected by SSCA or sequencing (Figure 1C).

U nrelated families 2, 5, 36 and 39 had the mutations $312 \mathrm{C}>\mathrm{G}(\mathrm{ex} 4), 608 \mathrm{C}>\mathrm{T}(\mathrm{ex} 6), 625 \mathrm{C}>\mathrm{G}(\mathrm{ex} 6)$ and $554 \mathrm{C}>\mathrm{A}($ ex 6$)$, respectively. A dditional mutation data are shown in Table 4 . We did not find any mutations in

Table 4 R S patients and X LR S1 mutations identified in this study

\begin{tabular}{|c|c|c|c|c|c|}
\hline $\begin{array}{l}\text { Mutation at } \\
\text { nucleotide level }\end{array}$ & $\begin{array}{l}\text { A ffected } \\
\text { exon }\end{array}$ & $\begin{array}{l}\text { M utation at } \\
\text { amino acid level }\end{array}$ & $\begin{array}{l}\text { M ethod used } \\
\text { for rapid detection }\end{array}$ & $\begin{array}{l}\text { Patient } \\
\text { group }\end{array}$ & $\begin{array}{l}\% \text { of known } \\
\text { Finnish patients }\end{array}$ \\
\hline $214 G>A$ & 4 & Glu72Lys & L oss of Taql & Western I & $70 \%^{a}$ \\
\hline $221 G>T$ & 4 & G ly74Val & Creation of $T s p R I$ & Western II & $6 \%$ \\
\hline $312 C>G$ & 4 & A sn 104Lys & Creation of $\mathrm{H}$ infl & Family 2 & $2 \%$ \\
\hline $325 G>C$ & 4 & G ly109A rg & SSCA & Northern & $19 \%^{\mathrm{a}}$ \\
\hline $554 C>A$ & 6 & Thr185Lys & SSCA & Family 39 & $1 \%$ \\
\hline $608 C>T$ & 6 & Pro203L eu & L oss of M aell & Family 5 & $2 \%$ \\
\hline $625 C>G$ & 6 & A rg209G ly & L oss of A cil & Family 36 & $0.3 \%$ \\
\hline
\end{tabular}

a denotes that the number is derived including patients which belong to the same pedigree. M utation analysis was not performed on all of these patients; $36 \%$ of the Western R S patients and $44 \%$ of the Northern R S patients were included in the analysis. 
A

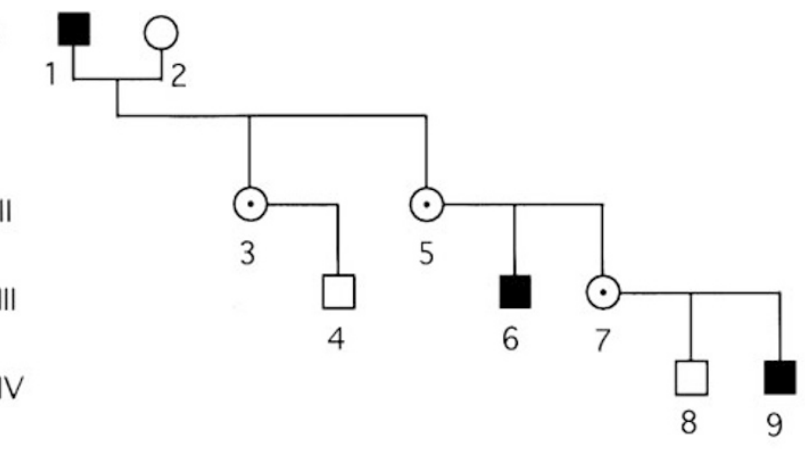

MW $\begin{array}{lllllllll}1 & 2 & 3 & 4 & 5 & 6 & 7 & 8 & 9\end{array}$

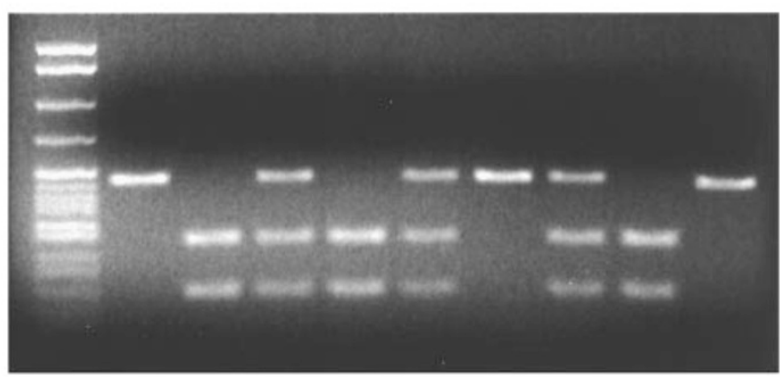

B

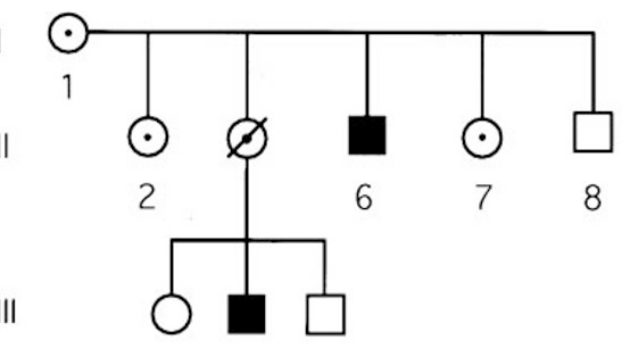

$\begin{array}{lll}3 & 4 & 5\end{array}$

$\begin{array}{llllllll}1 & 2 & 3 & 4 & 5 & 6 & 7 & 8\end{array}$

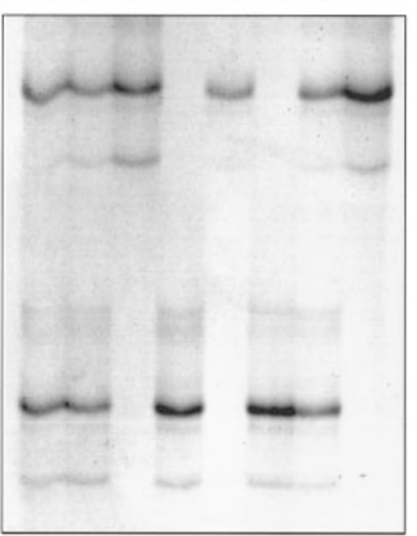

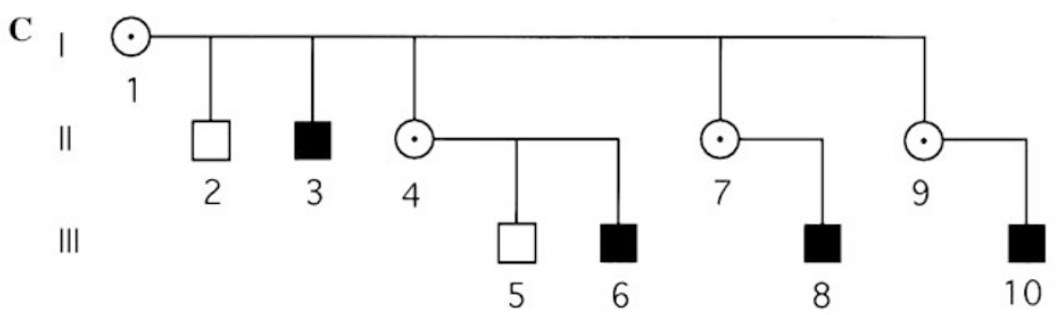

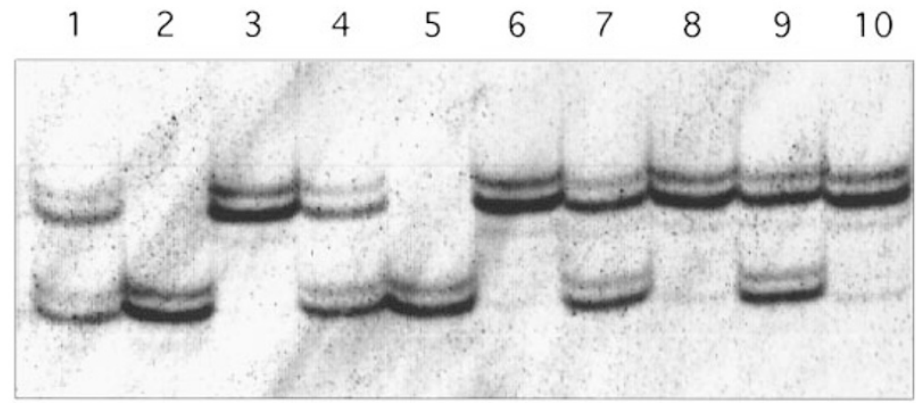

Figure 1 D etection methods for the Finnish founder mutations, showing the segregation of each mutation in a representative family. a) Taql restriction enzyme analysis of the Western I mutation. In affected family members $(1,6,9)$ the $220 \mathrm{bp} \mathrm{PCR} \mathrm{product} \mathrm{is} \mathrm{uncut}$ due to the loss of the Taql recognition site. In healthy individuals $(2,4,8)$ the $220 \mathrm{bp}$ product is digested into $135 \mathrm{bp}$ and $85 \mathrm{bp}$ fragments. Heterozygous carriers $(3,5,7)$ show all the three fragments. Molecular weight marker is pB R 322/M spl. b) SSCA analysis of the Western II mutation. The numbers above the lanes correspond with those in the pedigree. c) SSCA analysis of the Northern mutation. The numbers above the lanes correspond with those in the pedigree. 
one R S patient (unrelated family 41) after sequencing all exons, their flanking regions, and the $3^{\prime}$ UTR .

The segregation of each mutation in a family was confirmed either by SSCA or restriction enzyme based assay. A fter the seven mutations were identified, mutation analysis was performed for all the 118 patients according to their haplotype. A II exons were sequenced only in a few representatives of each mutation group. We did not find any second alterations. None of the $X$ LRS1 mutations identified in this study, 214G $>A$, $221 \mathrm{G}>\mathrm{T}, 312 \mathrm{C}>\mathrm{G}, 325 \mathrm{G}>\mathrm{C}, 554 \mathrm{C}>\mathrm{A}, 608 \mathrm{C}>\mathrm{T}$, $625 C>G$, were found in 100 control $X$-chromosomes and are therefore likely to be pathogenic. Mutation $325 \mathrm{G}>\mathrm{C}$ has been described earlier by Sauer et al ${ }^{18}$ and mutations $214 \mathrm{G}>\mathrm{A}, 221 \mathrm{G}>\mathrm{T}$, and $608 \mathrm{C}>\mathrm{T}$, by the $\mathrm{R}$ etinoschisis Consortium. ${ }^{19}$

\section{Geographical Distribution and Age}

Estimations of the Finnish XLRS1 Mutations

The geographical distribution of the birthplaces of 54 carrier females, including all mutation types, is shown in Figure 2. We detected a large clustering of Western I mutations in a well defined south-western region of Finland. A relatively high frequency of RS was also noted in the region of Oulu where the Northern mutations have accumulated. A third smaller clustering of mutations was detected in the parishes neighbouring the town of Pori, very close to Western I families. Two of the unrelated mutations were identified in families living in the Northern parts of Finland, overlapping with the region of the Northern mutation. The other two unrelated mutations were found in the families living farthest to the East. All in all, most Finnish RS patients are clearly clustered in Northern and South Western Finland (Figure 2), and have one of the three major mutations.

O ur earlier haplotype analyses, performed using RFLP markers spanning a region of $11 \mathrm{cM}$, had suggested the existence of two distinct founder haplotypes and therefore two founder mutations. ${ }^{24}$ In those studies $75 \%$ of the Northern families and $76 \%$ of the Western families shared a common haplotype between the markers DX S207-DX S41 (11 cM). Combining our previous and present haplotype data with the new mutation data, the Northern families share a common haplotype between the markers DXS7161-DXS207 $(7 \mathrm{CM})^{15,24}$ and the Western I families between the markers DXS7161-DXS1195 (1 CM ; provided that we postulate mutations in markers D XS418 and TA A A 2), suggesting that the Western I mutation is older than the Northern mutation. ${ }^{13,24}$

\section{Discussion}

This paper describes the Finnish mutations found in the $X L R S 1$ gene. One third of all known Finnish RS patients, 55 families ( 118 patients) were analysed in this study. Haplotype analysis with eight markers covering the $770 \mathrm{~kb}$ interval CA 1-DXS7161 revealed eight

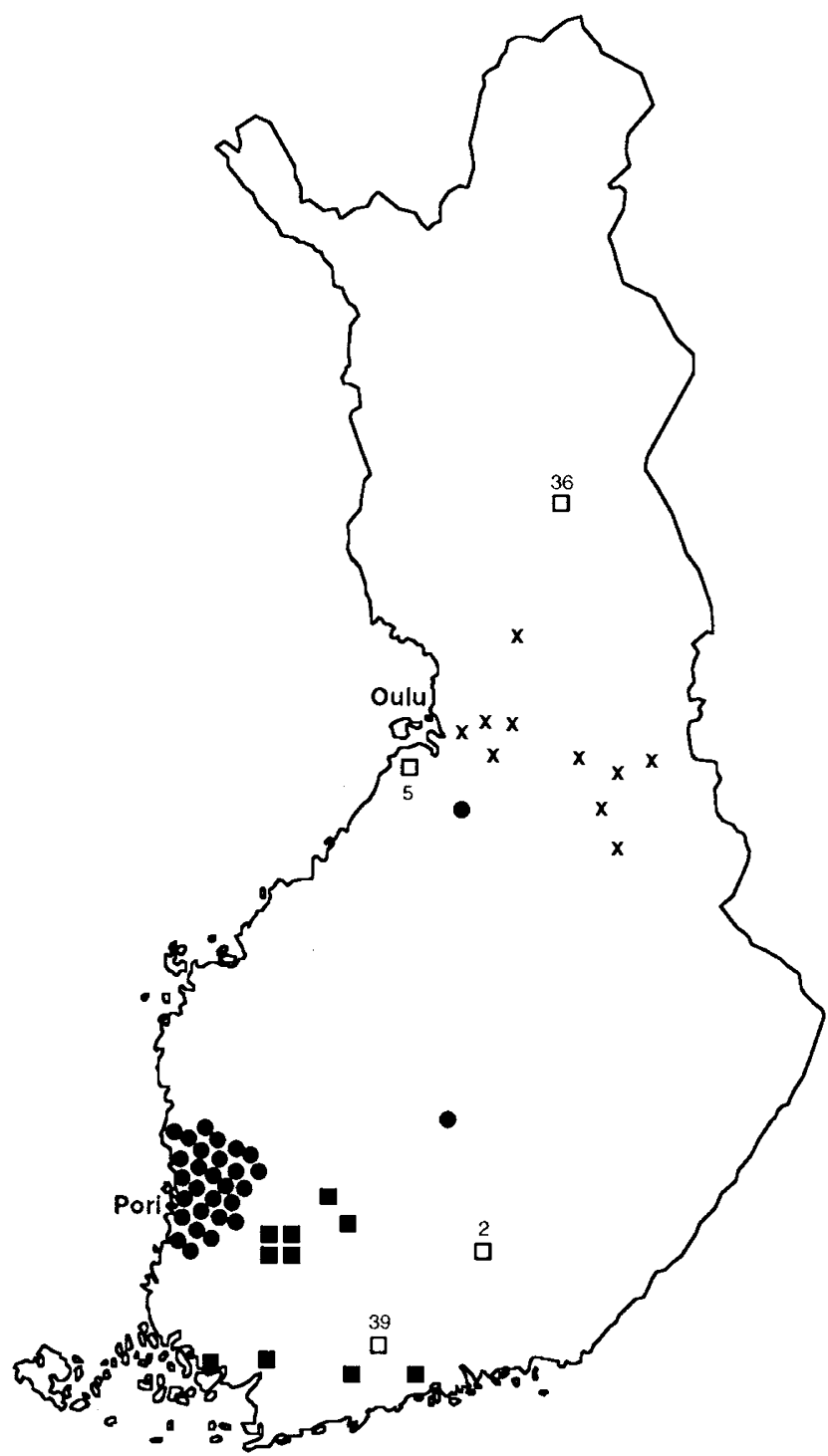

Figure 2 A map of Finland showing the birthplaces of 54 carrier females. The different mutation types are indicated by: - = Western I mutation; $\boldsymbol{\square}=$ Western II mutation; $\mathbf{X}=$ Northern mutation; $\square$ = unrelated families; $2=$ Fam 2; $312 \mathrm{C}>\mathrm{G} ; 5=$ Fam 5; 608C > T; $36=$ Fam 36; $625 \mathrm{C}>\mathrm{G}$; $39=$ Fam 39; 554C >A 
clearly distinct haplotypes. A fter sequencing the coding region of the $X L R S 1$ gene, we identified seven missense mutations, all in exons 4 and 6 . Based on the genealogical data and the mutation results, $70 \%$ of the Finnish RS patients carry the Glu72Lys (Western I) mutation. The high frequency of this missense mutation has also been observed in another study, where it was identified in 34 apparently unrelated patients, comprising $14 \%$ of all the RS mutations reported. ${ }^{19}$ The Northern mutation (G ly109A rg) accounted for approximately $19 \%$ of the Finnish RS mutations, being the second most common mutation in Finland. Surprisingly, a third founder mutation ( $G$ ly74Val) was identified in a group of families from Western Finland. Gly74Val accounts for $6 \%$ of all Finnish X LR S1 mutations. Thus, the three amino acid substitutions G Iu72L ys (Western I), G ly109A rg (Northern), G ly74Val (Western II) are responsible for approximately $95 \%$ of all RS cases in Finland. In addition to these founder mutations, four mutations (A sn104Lys, Pro203L eu, A rg209G ly, Thr185Lys) were identified in individual families. All the nucleotide changes found in this study occurred at $C$ or $\mathrm{G}$ nucleotides. However, only the mutation in family 5 (608C > T, CCG > CTG) shows the typical CG to TG transition affecting a CPG dinucleotide, which is known to be prone to $C>T$ transitions. ${ }^{29}$ Three of the mutations reported in this paper, $312 C>G \quad($ Fam 2) in exon 4, 554C > A (Fam 39) in exon 6 , and $625 C>G($ Fam 36) in exon 6, have not been found in any other E uropean or N orth A merican R S patient, ${ }^{18,19}$ and are thus novel XLRS1 mutations. All the Finnish mutations are clustered in the C-terminus of the X L RS1-gene product, supporting the notion that the $\mathrm{N}$-terminal part of the protein is functionally less important. ${ }^{18,19}$

Intragenic deletions, splice site mutations, nonsense mutations and frameshift mutations can cause major changes in the protein structure, often resulting in severe dysfunction of the protein. By contrast, the functional consequences of missense mutations are usually harder to predict. The XLRS1 gene has a well conserved discoidin domain. ${ }^{18}$ B ased on the alignment of the discoidin domain sequences, it has been observed that some of the RS amino acid substitutions introduce amino acids which are never used at this particular position in discoidin domains of other proteins. ${ }^{19}$ From this point of view, the most interesting amino acid substitution is the proline to leucine change $(608 \mathrm{C}>\mathrm{T})$, found in family 5 . The wild type proline at position 203 is one of the most conserved amino acids in discoidin motifs. It is present in all the protein sequences containing discoidin domains that were aligned by the RS Consortium. ${ }^{19}$ Replacement of a highly conserved proline residue by a leucine is likely to change the functional structure of the XLRS1 protein dramatically.

A lthough some mutations, like our most common Western I mutation Glu72Lys, change amino acids at less conservative positions, they can still cause considerable changes in proteins. In this mutation an acidic glutamic acid residue is changed to a basic lysine. Charged groups of basic and acidic amino acids have key roles in stabilising specific protein conformations. ${ }^{30}$ Therefore, changes from acidic to basic amino acids at certain positions are likely to cause major changes of protein conformation. Mutations in families 2 and 39 (A sn104Lys and Thr185Lys) result in a change of an uncharged amino acid residue A sn/Thr to a positively charged Lys residue. G lycine to arginine (Gly109A rg) and arginine to glycine (A rg209G ly) substitutions were detected in Northern patients and in family 36 , respectively. These changes are expected to have conformational effects since glycine, the smallest of the amino acids, can fit into the 3-dimensional structure in regions that are inaccessible to other amino acids. ${ }^{30}$ It is difficult

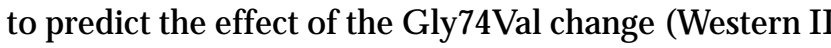
mutation), because both the amino acids, G ly and Val, are small, nonpolar neutral residues. The mutant proteins as well as the wild type X LR S1 protein have to be characterised further before one can draw any firm conclusions about the functional consequences.

In one Finnish RS patient the molecular change underlying the disease is still unknown. We were unable to identify a mutation by direct sequencing of all six coding exons, their immediate flanking sequences and the $3^{\prime}$ and $5^{\prime}$ UTR regions. Because the patient is a sporadic case, this mutation might be a de novo rearrangement in the patient. Since we have not determined the mRNA levels, we cannot exclude mutations in enhancer regions or other changes that might influence the transcription. Other mutations might reduce the stability of the mRNA. The patient may also carry a mid-intron mutation which remains to be discovered. Although the clinical findings of the patient are typical for $\mathrm{X}$-linked retinoschisis, it cannot be ruled out that the patient might have autosomal recessive retinoschisis. ${ }^{31}$

Because the haplotypes of the patients in each mutation type are almost completely identical, we conclude that each mutation arose only once. A s stated 
earlier, the Western I mutation is also very common in other European and North A merican R S patients. It may be unlikely, though, that there is a common founder for all of these patients. We have identified the R S haplotypes of one Swedish and one Danish patient with a $214 \mathrm{G}>\mathrm{A}$ (Western I) mutation (unpublished, 1998). A Ithough the Swedish patient shared the same haplotype with the Finnish patients, it is probable that this patient's family emigrated from Finland to Sweden. The Danish patient had a different haplotype and the mutation most probably arose independently, as in many other European countries (haplotype data not available). The retinoschisis mutations do not seem to have any selective effects. As stated earlier, ${ }^{21}$ the disease is most likely underdiagnosed in most parts of the world. The high number of R S mutations identified in an isolated population (this study) gives further support to the idea that the frequency of RS must be higher than previously thought.

O ur studies suggest that most of the Finnish XLRS1 mutations are not very old. $O$ nly a few Finnish diseasecausing mutations, occurring throughout Finland, have expanded for over 100 generations. ${ }^{32}$ It has been estimated that mutations that occur in certain small geographical regions in Finland have existed only for 15-30 generations. ${ }^{33,34}$ Due to the fact that our RS families are closely related, and because of the scarcity of recombinations in the ancestral haplotypes of each mutation, we were not able to estimate the ages of the mutations by statistical analyses. ${ }^{35,36} \mathrm{O}$ ur age estimations of the mutations are thus based on the genealogical studies only. The progenitors of Western I, Western II and Northern pedigrees were born in 1732, 1806 and 1715, respectively. A ncestors can be easily traced back to the beginning of the 18th century but often there are no church registers preserved from earlier times. The Northern parts of Finland were inhabited in the $1700 \mathrm{~s},{ }^{37,38}$ and we estimate that the age of the Northern mutation is $>300$ years. With a typical human generation span of 25 years, this suggests that the mutation has segregated over 12 generations. The Western II mutation is much younger, about 200 years (approximately eight generations). The oldest founder mutation is clearly the Western I mutation. Based on the fact that the Western parts of Finland have been inhabited for at least 1000 years and approximately $70 \%$ of the Finnish patients carry the Western I mutation, this may have existed in the population at least twice as long as the Northern mutation. We estimate, but cannot yet prove, that the Western I mutation is $>600$ years old, corresponding to $>24$ generations. Based on the family data, the four individual mutations have existed for $1-5$ generations.

O ne of the early aims of this study was to determine whether there is a correlation between the molecular defect and the disease phenotype. No such correlation could be observed; the whole spectrum of retinoschisis phenotypes from almost total blindness to just a mild reduction of visual acuity were found in the groups of families carrying either the Northern, the Western I or the Western II mutation. These observations strongly suggest that other genetic factors, such as modifying genes or epigenetic factors most likely influence the phenotypic severity of this disorder.

A lthough we cannot predict the severity of the disease by identifying a specific mutation, we can offer the Finnish RS families reliable carrier and pre- and postnatal diagnostics. The analysis is presently done by restriction enzyme based methods and SSCA, but the most common Finnish mutations will soon be conveniently diagnosed by DNA microchip technology.

\section{Acknowledgements}

The authors thank the RS families for cooperation, the members of the R etinoschisis Consortium for collaboration, Sinikka Lindh for genealogical studies and sample collection, K irsi A lakurtti for technical assistance and the D epartment of $\mathrm{B}$ iosciences, $\mathrm{U}$ niversity of $\mathrm{H}$ elsinki, for sequencing. This study was supported by grants from the European Communities Grant PL 950889, The A cademy of Finland, The Finnish Foundation for Pediatric Research (Ulla H jelt Fund), the Sigrid J uselius Foundation, and the Finnish State G rant TY H 8301.

\section{References}

1 A rden $G B$, Gorin M B, Polkinghorne PJ, Jay M, Bird A C: $D$ etection of the carrier state of $X$-linked retinoschisis. A m J O phthalmol 1988; 105: 590-595.

2 Forsius $H$, E riksson A, Nuutila A, Vainio-Mattila $B$, $\mathrm{K}$ rause $\mathrm{U}: \mathrm{A}$ genetic study of three rare retinal disorders: dystrophia retinae dysacusis syndrome, $\mathrm{X}$-chromosomal retinoschisis and grouped pigments of the retina. Birth D efects 1971; 7: 83-98.

3 Deutman AF: Vitreoretinal dystrophies. In: Krill A, A rcher D (eds). Hereditary Retinal and Choroidal Diseases. H arper \& R ow: N ew Y ork, 1977, pp 1043-1108.

4 George ND, Y ates JR, Moore AT: Clinical features in affected males with $X$-linked retinoschisis. A rch 0 phthalmol 1996; 114: 274-280.

5 Forsius $\mathrm{H}$, Vainio-M attila $\mathrm{B}$, E riksson A : X-linked hereditary retinoschisis. Br J O phthalmol 1962; 46: 678-681. 
$6 \mathrm{U}$ chino $M$, Shimizu $H$ : A family with congenital retinoschisis including a female patient. Jap J Clin O phthalmol 1976; 30: 145-151.

$7 \mathrm{H}$ amaguchi $\mathrm{H}$, Wada I, Takigawa J, Y amada $\mathrm{H}$, M ori $\mathrm{K}$, $\mathrm{U} \mathrm{ji} Y:$ A case of congenital retinoschisis in a 34-week gestation female infant. Nippon Ganka Gakkai Zasshi 1989; 93: 575-580.

$8 \mathrm{H}$ ommura $\mathrm{S}, \mathrm{Nakano} \mathrm{H}, \mathrm{H}$ amaguchi $\mathrm{H}$ : A family with foveal retinoschisis including a female with Turner's syndrome. O phthalmology 1982; 36: 291-296.

9 Weber $\mathrm{BH}$, Janocha $\mathrm{S}$, Vogt $\mathrm{G}$ et al: X-linked juvenile retinoschisis (RS) maps between DXS987 and DXS443. Cytogenet Cell G enet 1995; 69: 35-37.

10 George NDL, Payne SJ, Bill R M, B arton DE, M oore AT, Yates JRW: Improved genetic mapping of $X$-linked retinoschisis. J M ed G enet 1996; 33: 919-922.

11 Pawar H, Bingham EL, H iriyanna K, Segal M, Richards JE, Sieving PA : $X$-linked juvenile retinoschisis: localization between (DX S1195, DX S418) and A FM 291wf5 on a single YA C. H um Hered 1996; 46: 329-335.

12 van de Vosse $E$, B ergen A A B, M eershoek $E$ J et al: A n $X p 22.1-X$ p22.2YAC contig encompassing the disease loci for R S, KFSD, CLS, HY P and RP15: refined localization of R S. Eur J H um G enet 1996; 4: 101-104.

13 H uopaniemi L, R antala A, Tahvanainen E, de la Chapelle A , A litalo T: L inkage disequilibrium and physical mapping of X-linked juvenile retinoschisis. A m J H um G enet 1997; 60: $1139-1149$.

14 A litalo $T$, Francis $F$, K ere J, L ehrach $H$, Schlessinger $D$, Willard $\mathrm{HF}$ : A $6 \mathrm{Mb}$ YAC contig in Xp22.1-Xp22.2 spanning the DXS69E, XE 59, GLRA 2, PIGA, GRPR, CA L B 3 and PHKA 2 genes. G enomics 1995; 25: 691-700.

15 Ferrero GB, Franco B, Roth EJ et al: A n integrated physical and genetic map of a $35 \mathrm{Mb}$ region on chromosome Xp22.3-X p21.3. Hum Mol Genet 1995; 4: $1821-1827$

16 Walpole SM, Nicolaou A, Howell GR et al: Highresolution physical map of the $X$-linked retinoschisis interval in X p22. G enomics 1997; 44: 300-308.

17 Sanger Centre, $\mathrm{H}$ inxton, U K : http://www.sanger.ac.uk

18 Sauer C, G ehrig A, Warneke-Wittstock R et al: Positional cloning of the gene associated with $X$-linked juvenile retinoschisis. $N$ at $G$ enet 1997; 17: 164-170.

19 The R etinoschisis Consortium: Functional implications of the spectrum of mutations found in 234 cases with $\mathrm{X}$-linked juvenile retinoschisis (XLR S). $\mathrm{H}$ um M ol G enet 1998; 7: 1185-1192.

20 Springer WR, Cooper DN, Barondes SH : D iscoidin I is implicated in cell-substratum attachment and ordered cell migration of Dictyostelium discoideum and resembles fibronectin. Cell 1984; 39: 557-564.

21 de la Chapelle A, A litalo T, Forsius $\mathrm{H}$ : X-linked juvenile retinoschisis. In: W right $A$, Jay $B$ (eds). M olecular $G$ enetics of Inherited E ye Disorders, 1st edn. H arwood A cademic Publishers: Chur, 1994, pp 339-357.

22 Vainio-M attila $B$, E riksson AW, Forsius $H$ : $X$-chromosomal recessive retinoschisis in the region of Pori. A cta O phthalmol 1969; 47: 1135-1148.
23 Forsius $H$, Eriksson AW, Damsten $M$ : Progression in juvenile $\mathrm{X}$-chromosomal retinoschisis. A cta O phthalmol 1990; 68 (Suppl. 195): 113-119.

24 A litalo T, K ruse TA, de la Chapelle A : R efined localization of the gene causing $X$-linked juvenile retinoschisis. Genomics 1991; 9: 505-510.

25 http://www-genome.wi.mit.edu/cgi-bin/primer/primer3.cgi

26 Bassam BJ, Caetano-A nolles G, G resshoff PM : Fast and sensitive silver staining of DNA in polyacrylamide gels. A nal Biochem 1991; 196: 80-83.

27 Orita M, Suzuki Y, Sekiya T, H ayashi K: Rapid and sensitive detection of point mutations and DNA polymorphisms using the polymerase chain reaction. Genomics 1989; 5: 874-879.

28 E riksson AW, Fellman J, Vainio-Mattila $B$, Forsius $\mathrm{H}$ : $X$-chromosomal retinoschisis (retinal detachment) in Finland. Bull E urop Soc H um G enet 1969; 3: 67-76.

29 D uncan B, Miller J: Mutagenic deamination of cytosine residues in D NA. Nature 1980; 287: 560-561.

30 R odwell V W: Section I: Structures \& functions of proteins \& enzymes: A mino acids. In: M urray RK, Granner DK, M ayers PA, Rodwell VW (eds). H arper's B iochemistry, 22nd edn. A ppleton \& Lange: London, 1990, pp 21-31.

31 Forsius $H$, E riksson AW, Damsten $M$, A lanko H : R ecessive central retinoschisis. Documenta O phthalmol Proc Ser 1978; 17: 345-359.

$32 \mathrm{H}$ ästbacka J, de la Chapelle A, Kaitila I, Sistonen P, Weaver A, Lander E : L inkage disequilibrium mapping in isolated founder populations: diastrophic dysplasia in Finland. $\mathrm{N}$ at $\mathrm{G}$ enet 1992; 2: 204-211.

$33 \mathrm{H}$ öglund $\mathrm{P}$, Sistonen $\mathrm{P}, \mathrm{N}$ orio $\mathrm{R}$ et al: Fine mapping of the congenital chloride diarrhea gene by linkage disequilibrium. A m J Hum G enet 1995; 57: 95- 102.

34 Varilo T, Savukoski M, N orio R, Santavuori P, Peltonen L, Järvelä I: The age of human mutation: genealogical and linkage disequilibrium analysis of the CLN 5 mutation in the Finnish population. Am J Hum Genet 1996; 58: 506-512.

35 M oisio A -L, Sistonen P, Weissenbach J, de la Chapelle A, Peltomäki $P$ : A ge and origin of two common MLHI mutations predisposing to hereditary colon cancer. A m J H um G enet 1996; 59: 1243-1251.

36 Carrasquillo $\mathrm{M}$, Z lotogora J, B arges S, Chakravarti A : Two different connexin 26 mutations in an inbred kindred segregating non-syndromic recessive deafness: implications for genetic studies in isolated populations. $\mathrm{H}$ um M ol G enet 1997; 6: 2163-2172.

37 de la Chapelle A: Disease gene mapping in isolated human populations: the example of Finland. J M ed G enet 1993; 30: 857-865.

38 Vahtola J: The main phases of colonization in northern Finland. In: Julku K, Fält OK, H ovi K, Salo U, Vahtola J (eds). Faravid: A cta Societatis H istoricae Finlandiae Septentrionalis. G ummerus: J yväskylä, 1993, pp 141-147. 